\title{
A CRITICAL REVIEW ON \\ BALACHATURBHADRA CHURNA: AN EFFECTIVE AYURVEDA FORMULATION FOR THE PEDIATRIC AGE
}

\author{
Abhishek Joshi ${ }^{1 *}$, Shrikrishna Rajagopala ${ }^{2}$, and Patel Kalpana S. ${ }^{3}$ \\ ${ }^{1}$ Universitas Hindu Indonesia, Denpasar, Bali, Republic of Indonesia \\ ${ }^{2}$ Department of Bala Roga, All India Institute of Ayurveda, New Delhi \\ ${ }^{3}$ Department of Kaumarbhritya, IPGT \& RA, Gujarat Ayurved University, Jamnagar, Gujarat \\ ${ }^{*}<$ drabhishekjoshi@yahoo.com>
}

\begin{abstract}
Balachaturbhadra Churna offers a multitude of health benefits for which it has become so poapular prescription by Kaumarbhritya practioners of Ayurveda. It is a combination of four drugs Musta, Pippali, Ativisha and Karkatashringi. This combination was first mentioned in Chakradatta and has been in practice since a millennium. Many queries have been raised on the usage of Aconite species of drugs recently, thus doubting the safety and efficacy of Balachaturbhadra Churna. Very few works have been published on Balachaturbhadra Churna till now. The aim of the present study was to compile and review such available references from classics and research works published on Balachaturbhadra Churna. Total five studies are published on Balachaturbhadra Churna, which revalidated the impact of classical guidelines. The research papers revealed standards of Quality Control and pharmacological efficacy of the drug. All the experimental studies revealed that Balachaturbhadra Churna is having no toxic hazards at very higher Dose levels, proving it safe for therapeutic use. Though certain limitations were observed in these researches, the results can be considered as a lead for further well stratified clinical studies.
\end{abstract}

Keywords: Balachaturbhadra Churna, pharmacology, Quality Control, standards, therapeutic use

\section{Introduction}

Very few medicaments have been described in Ayurveda specially indicated for their usage in children.
One among them is Balachaturbhadra

Churna (BCBC) which is a very

popular and a beneficial compound

formulation in pediatric usage. It is a 
widely practiced formulation that is indicated in respiratory disorders, fever, diarrhoea and vomiting of children (Joshi, et.al., 2013).

The nomenclature of Ayurveda was primarily designed to help a physician select a plant for medicinal purposes. This is divided into three sub-topics named Nama (name), Rupa (form) and Yukti jnana (therapeutic usage), which constitutes the three-tier understanding of ausadhi (drug materials)

(Viswanathan et.al., 2013). Bala means a child, Chatuhu means combination of four, and Bhadra means which is beneficial or best (Radhakantadeva, 1961). Thus the term Balachaturbhadra denotes a combination of four drugs that are meant for use in children. The prefix Bala suggests that the combination is specially indicated in children and is potent enough to cure the diseases of the pediatric age group.

India has a rich heritage of traditional herbal medicines. With the emerging interest of the world to adopt and study traditional systems, many opportunities have opened up to take advantage of the potential based on different healthcare systems (WHO, 2000). The Ayurvedic pharmaceutical preparations evolved gradually from a simpler form to more complex forms based on plants and plant mineral combinations. This is the unique feature of herbal treatments, that one plant species can cure a particular disease and also can cure a number of other ailments in combination with other plant species. The clinical effect also varies with different dosages, forms and modes of administration.

Very few research have been published on Balachaturbhadra Churna. Ativisha (Aconitum heterophyllum Wall.), one of the ingredients in this combination has been questioned by modern research industry for its safety. Aconite species are reported for its cardiotoxic as well as neurotoxic effects (Chan, 2009) but no studies related to the toxic effect of Aconitum heterophyllum Linn. in particular have been reported. Nonetheless the use of this formulation since millennia without reports of any untoward effect itself is a testimony to its safety. Still, an evaluation based on objective controlled experiments and a standardization of various parameters will provide proof for the undoubted usefulness of the drug. In this article an attempt has been made to compile and critically evaluate the ancient classics and recent research publication of the drug Balachaturbhadra Churna.

\section{Materials and Methods}

Reviews of all references available for Balachaturbhadra Churna in classical texts as well as very recent literature were explored. Thorough searches were carried out on internet sources while articles published on Balachaturbhadra Churna in various journals were analyzed for 
comprehensive understanding of the formulation.

\section{Observations}

The observations made from the review are mentioned under various headings as follows.

1. Classical references of $\mathrm{BCBC}$

Balachaturbhadra Churna is mentioned for the first time in the text Chakradatta (Chakradatta et.al., 1976). Later period the same reference is found in several text books. The detailed description of references available is shown in table 1.

All the texts have mentioned the same four ingredients. Table 2 shows the constituents of Balachaturbhadra Churna. It is a fine powder prepared by mixing equal proportions of Musta (Cyperus rotundus Linn) rhizome, Pippali (Piper longum Linn) fruit, Ativisha (Aconitum heterophyllum Wall.) root and Karkatashringi (Pistacia integerrima Stew.) gall. It is given in the treatment of various pediatric diseases like Jvara (fever), Atisara (diarrhoea), Svasa and Kasa (respiratory disorders) and Chardi (vomiting) (Chakradatta, 1976, Sharma and Vijnana, 2001).

2. Pharmaceutical standardization Ajazuddin et.al. in 2012 carried out investigations to study the physicochemical, phytochemical and spectrophotometric analysis of formulation (Ajazuddin, 2012). The values of percentage loss on drying, angle of repose, Hausner ratio, Carr's index of the lab formulation were calculated as $6.84 \pm 0.224,27.36$, 1.25 and 20 respectively. Total ash, acid insoluble ash and water soluble ash were found $8.148 \pm 0.337$, $3.281 \pm 0.286$, and $45.602 \pm 0.414$ respectively. Alcoholic and aqueous extracts of formulations and ingredients were prepared and evaluated for phytochemical analysis and the results of extractive values shows higher alcoholic extractive value (39.294 \pm

Table 1. References available for Balachaturbhadra Churna

\begin{tabular}{clcc}
\hline Sr. No. & \multicolumn{1}{c}{ Name of text books } & Reference & Time period \\
\hline 1 & Cakradatta & $64 / 22$ & $11^{\text {th }}$ century A.D. \\
2 & Gadanigraha & $11 / 93$ & $12^{\text {th }}$ century A.D. \\
3 & Sharangadhar Samhita & $6 / 16$ & $13^{\text {th }}$ century A.D. \\
4 & Bhavaprakasha & $71 / 151$ & $16^{\text {th }}$ century A.D. \\
5 & Yogaratnakara & $71 / 39$ & $17^{\text {th }}$ century A.D. \\
6 & Bhaishajya Ratnaval & $71 / 39$ & $18^{\text {th }}$ century A.D. \\
7 & Bhaishajya Samhita & $7 / 50$ & $20^{\text {th }}$ century A.D. \\
8 & Bharat Bhaishajya Ratnakar & $7 / 24$ & $20^{\text {th }}$ century A.D. \\
9 & Bala Tantra & $13 / 10$ & $20^{\text {th }}$ century A.D. \\
10 & Ayurvedic formulary of India & part $1 /$ page 92 & $20^{\text {th }}$ century A.D. \\
\hline
\end{tabular}


Table 2. Constituents of Balachaturbhadra Churna

\begin{tabular}{clcc}
\hline Sr. No. & \multicolumn{1}{c}{ Name of text books } & Reference & Time period \\
\hline 1 & Cakradatta & $64 / 22$ & $11^{\text {th }}$ century A.D. \\
2 & Gadanigraha & $11 / 93$ & $12^{\text {th }}$ century A.D. \\
3 & Sharangadhar Samhita & $6 / 16$ & $13^{\text {th }}$ century A.D. \\
4 & Bhavaprakasha & $71 / 151$ & $16^{\text {th }}$ century A.D. \\
\hline
\end{tabular}

2.226) of formulation depict that alcohol is a better solvent for extraction. Three laboratory batches of formulation and Piper longum powder were estimated for their piperine content against standard piperine solution on double beam UV-Visible spectrophotometer at $\lambda \max 342.5 \mathrm{~nm}$.

Shahebaz et.al. in 2012 made an attempt to evaluate and compare market formulation with in-house sample of Balchaturbhadra Churna by performing physico-chemical screening, phytochemical screening, microscopic characterization and fluorescence analysis (Ghadiyali et.al., 2012). Respective physical parameters observed for standard and market preparation of Balchaturbhadra Churna were Bulk Density (gm/ ml.) 0.5882 and 0.434 , Tap Density $(\mathrm{gm} / \mathrm{ml}) 0.8$ and 0.625 , Carr's Index 26.47 and 30.43, Hausner's Ratio 1.36 and 1.43 and Angle of Repose 32.32 and 34.43. Morphological study of Balachaturbhadra Churna showed fine consistency for standard formulations and very fine for market formulations; colour was brown for standard formulations and greyish brown for market formulation, while it had a pleasant odour and bitter taste for both the formulations. Quantitative Analysis of microscopic constituent of standard and market formulations of Balachaturbhadra Churna observed were 3.43 and 3.24 for Starch Grains, 55.12 and 52.56 for Xylem vessels and it was 170.76 and 176.34 for fibres (length). Screening of phytoconstituents in standard and market formulations of Balachaturbhadra Churna showed presence of alkaloids, flavonoids, phenolics, carbohydrates, tannins, Sterols and triterpenoids whereas coumarins and saponins were absent.

Estimation of phytoconstituents in standard and market formulations of Balachaturbhadra Churna were respectively $0.107 \%$ and $0.096 \%$ for Flavonoids, $0.84 \%$ and $0.76 \%$ for $\mathrm{Na}+$ ion salts, $0.62 \%$ and $0.38 \%$ for $\mathrm{K}+$ ion salts, $2.91 \%$ and $3.74 \%$ for Tannins and for Crude fibre content it was $15.5 \%$ and $13 \%$. Fluorescence analysis was performed by observing the powder of the standard and market formulation of Balachaturbhadra Churna with $1 \mathrm{~N}$ HCL, 1N H2SO4, 1N HNO3, aquous and alcoholic $\mathrm{NaOH}$, Iodine solution, $\mathrm{KOH}$ and $\mathrm{NH} 3$ and the fluorescence in day light and in UV light was compared 
for both the samples. After analysis it was observed that market samples matched exactly with that of authentic standards of in-house formulation after performing the standardization.

Abhishek Joshi et.al. in 2013 made an attempt to develop Pharmacognostical, Pharmaceutical and HPTLC standards for Balachaturbhadra Churna. Organoleptic characters observed for Balachaturbhadra Churna were light brown colour, spicy pungent odour, Kashaya - Tikta (astringent bitter) taste and fine consistency of the powder. Powder microscopy shows striking characters of all 4 individual constituents. Starch grains without hilum, dark brown colouring matter, annular vessels and lignified fibres of Musta, starch grains without hilum, stone cells and oil globules form Pippali, simple and compound starch grains, cork cells, prismatic crystals of calcium oxalate and parenchyma cells from Ativisha, tannin content material, fragments of pitted vessels, vascular bundles along with tannin cells and epidermal cells from Karkatashringi.

Loss on drying, ash value, water soluble extract $\% \mathrm{w} / \mathrm{w}$, alcohol soluble extracts $\% \mathrm{w} / \mathrm{w}, \mathrm{pH}$ value of Balachaturbhadra Churna were $4.7 \% \mathrm{w} / \mathrm{w}, 5.75 \% \mathrm{w} / \mathrm{w}, 29.3 \% \mathrm{w} / \mathrm{w}$, $27.3 \% \mathrm{w} / \mathrm{w}$ and 6 respectively. Particle size of Churna was ranging from 60120 mesh. $3.209 \mathrm{~g}, 2.345 \mathrm{~g}, 1.360 \mathrm{~g}$, and $3.019 \mathrm{~g}$ was obtained from $>60,61-85$, $86-120$ and $>120$ mesh respectively.
Qualitative test for various functional groups revealed the presence of carbohydrates, steroids, cardiac glycosides, flavanoids, alkaloids and tannins in the formulations. Saponin was absent in Churna. On performing HPTLC, the chromatogram showed 17 peaks with Rf values at $254 \mathrm{~nm}$; while at $366 \mathrm{~nm}$ the chromatogram showed 14 spots. Commonly seen $\mathrm{Rf}$ values at both $254 \mathrm{~nm}$ and $366 \mathrm{~nm}$ were $0.14,0.18$, $0.23,0.29,0.34,0.35,0.47,0.53$, and 0.58 .

3. Toxicity study

Parmar Parag et.al., in 2011 conducted studies on acute toxicity study on albino rats. Acute toxicity study was carried out as per WHO guideline for acute toxicity test and modified as per experimental need (Anonymous, 1993). The rats were observed closely for behavioural changes, sign and symptoms of toxicity and mortality continuously for the first four hours and thereafter periodically up to 14 days. Balacaturbhadrika Churna did not produce any signs and symptoms of toxicity and mortality up to a dosage of $2000 \mathrm{mg} / \mathrm{kg}$ in rats.

Nariya M. et.al., in 2011 published data related toxicological study of Balachaturbhadrika Churna. The study was carried out by administering Balacaturbhadrika Churna in a dose up to $2000 \mathrm{mg} / \mathrm{kg}$ orally once. For long-term toxicity, Balacaturbhadrika Churna was administered in doses of 450 and $900 \mathrm{mg} / \mathrm{kg}$ orally for 
45 consecutive days. The effects of the drug on ponderal changes, hematological, biochemical and histological parameters were noted.

The acute toxicity experiment showed that the drug did not produce any signs and symptoms of toxicity (or mortality) up to the dose of $2000 \mathrm{mg} /$ $\mathrm{kg}$. This dose is more than 20 times the therapeutic equivalent dose in rats, clearly indicating that the formulation is unlikely to induce any drastic toxic effects. Long-term toxicity results showed that, even at higher dose of 900 $\mathrm{mg} / \mathrm{kg}$, Balacaturbhadrika churna did not affect the parameters studied to a significant extent.

The effect of Balacaturbhadrika Churna was studied on bone marrow cellularity. The test drug did not affect the polychromatic normoblasts, erythrocytes and normoblast showing micronuclei at both the dose levels studied, in comparison to the control group. This suggests that it is not likely to have any mutagenicity potential. The histopathological studies of 16 organs showed that Balacaturbhadrika Churna at $450 \mathrm{~g} / \mathrm{kg}$ increased the cellularity in the thymus and spleen. Other organs exhibited normal cytoarchitecture suggesting that the preparation is devoid of serious organ degenerative potential at this dose level.

4. Pharmacological study pertaining to its efficacy

Parmar Parag et.al. also conducted studies on cell mediated immunity, antibody formation and relative weight of spleen and the thymus of albino rats (Parmar, et.al., 2011). For cell mediated immunity Balacaturbhadrika Churna at dose of $100 \mathrm{mg} / \mathrm{kg}$ and $200 \mathrm{mg} /$ $\mathrm{kg}$ produced statistically significant changes on comparison with control group at 24 and 48 hours. Thus it can be inferred that the test drug produces significant suppression of cell mediated immunity.

Balacaturbhadrika Churna did not affect antibody formation against Sheep $\mathrm{RBC}$ at significant level. Examination of spleen and thymus sections under microscope showed increase in features of increased cellularity. Though increased cellularity of thymus and spleen along with increased proportion of white pulp was observed, it does not seem to indicate immune stimulation rather it may be the tissue response to the CMI suppression observed with the test drug.

5. Clinical studies conducted to assess its efficacy

No study has been published till now to assess the clinical efficacy Balachaturbhadra Churna.

\section{Discussion}

An overview of the classics of Ayurveda throws light into the specific features of a child, which make them a subject for special considerations. The descriptions given in different contexts include Dosha Dushya Malalpata (quantitative and qualitative wise less 
Dosha, Dushya, Mala), Soukumaryata (delicate by nature), Alpakayata (lower body mass index compared to adults), Sarvannanupa Sevana (not consuming all types of food), Aparipakwa Dhatu (immature state of Dhatus), Asampurna Bala (inadequate immunity), Kleshasahishnutwa (unable to withstand hardships), Ahara Sankarat Aniyatagni (unstable status of Agni as not acclimatized with different states of food materials) and Asamatvagata Prana Dosha Dhatu Maloujasam (unstable functional and structural entities in children) (Samhita, et.al. 2009, Vagbhata et.al., 2005, Agnivesha et.al., 2009, Vridhhajeevaka, et.al. 2009).

All these postulations give a clear idea about the Dehabala (body strength), Agnibala (strength of digestive fire) and Satwabala (mental status) of the pediatric age group. Moreover they provide an idea about the lowered immune status of the child that makes them more susceptible for repeated infections. Another aim behind these considerations is that the child cannot tolerate all forms of medicaments and many of the treatment procedures, so these aspects are to be well considered in the planning and implementation of treatment protocol. Balachaturbhadra Churna is one such formulation mentioned in classics specially meant for use in pediatric practice.

Chakrapani Dutta, the famous commentator on Charaka Samhita as well as Sushruta Samhita, in text Chakradatta mentioned the combination Balachaturbhadra Churna for the first time (Chakradatta et.al, 1976). Later to him almost all the renowned texts of Ayurveda including two from the famous Laghutrayees have described Balachaturbhadra Churna in their texts. The term Balacaturbhadrika has been used for Balachaturbhadra Churna in Bhaishajya Ratnavali (Dasa, 1983). There is no controversy regarding the constituents of Balachaturbhadra Churna mentioned in all texts of Ayurveda. The combination of these four drugs is unchanged in all these texts indicating the therapeutic effectiveness of this particular combination in pediatric disorders.

Total five works related to Balachaturbhadra Churna which are published till now, were compiled in this work.

Organoleptic studies reveal fine consistency, brownish appearance and bitter taste of the Churna (powder). All the studies of Churna which were analysed for Pharmacognosy were found having characters of all individual constituents. Striking characters like lignified fibres of Musta, starch grains without hilum from Pippali, cork cells, parenchyma cells from Ativisha were observed in all samples.

Physical parameters like bulk density, tap density, Carr's index, Hausner's ratio and angle of repose 
showed better flow property of Balachaturbhadra Churna. The loss on drying of any sample is directly related to its moisture content. The less value of moisture content could prevent bacterial, fungal or yeast growth (African pharmacopoeia, 1986). The values obtained in all studies were in accordance to the API standards (Anonymous, 2008). The ash value indicates the presence of inorganic and salt materials in the sample. The values obtained for all samples of Balachaturbhadra Churna were as per API standards except for one study by Ajazuddin et al. where it was partially higher (Saraf, 2012). This may be due to various factors involved right from cultivation of drug till manufacture of final product.

All the studies show high watersoluble and alcohol soluble extractive values. This indicates the amount of active constituent and the bioavailability of the plant, in given amount of plant material when extracted with respective solvents. The $\mathrm{pH}$ of Balachaturbhadra Churna was found acidic. Phytochemical screening reveals the presence of carbohydrates, steroids, glycosides, flavanoids, alkaloids, phenols and tannins in the formulations. Saponins is absent in Churna.

The Balachaturbhadra Churna did not modify humoral antibody formation, relative weight of spleen and the thymus of albino rats to significant extent. Immunological odema represents cell mediated immune response hence it can be inferred that the Balachaturbhadra Churna produces significant suppression of cell mediated immunity which is direct correlation of delayed type hypersensitivity (DTH) response and do not influence humoral immune response. The observed effect may be the main mechanism for the efficacy of the drug in respiratory disorders (Parmar, et.al., 2011). The acute and chronic toxicity experiments showed that the drug did not produce any signs and symptoms of toxicity even at very high dosages, which clearly indicates that the formulation is unlikely to induce any drastic toxic effect in spite of containing Aconitum species which is known for cardio-toxic and neurotoxic potential. The study on the effect of Balachaturbhadra churna on bone marrow cellularity suggests that it is not likely to have any mutagenicity potential (Nariya, et.al., 2011).

\section{Conclusion}

No clinical study has been published so far on this classical Ayurveda formulation. The doses employed for these toxicity studies as mentioned in pharmacology study were several times higher than normal clinical doses of Balachaturbhadra Churna, hence the observed changes will probably not become apparent at therapeutic dose level. This 
undoubtedly solves the safety concerns related to the presence of Aconitum species drug in the formulation. Thus
Balachaturbhadra Churna can be considered safe for clinical use.[]

\section{References}

Abhishek Joshi, Aparna K, Rajagopala S, K. S. Patel, C.R. Harisha and V. J. Shukla. Pharmacognostical and Pharmaceutical Assay of Balachaturbhadra churna - A Compound Ayurvedic Formulation. International Journal of Pharmaceutical \& Biological Archives 2013; 4(1): 170-174.

Acharya Sodhala, Gada Nigraha, Tripathi I. and Pandeya G. S. editor. Varanasi: Chaukhambha Samskrta Samsthana; 1994. p. 526.

African pharmacopoeia. General methods for analysis. Vol.2 (OAU/STRC) Lagos; 1986. P. 123.

Agnivesha, Charaka Samhita, Chakrapani commentary, Yadavji Trikamji Acharya editor. Varanasi: Chaukhambha Sanskrit Sansthan; 2009, Chikitsa Sthana, Yonivyapat Chikitsa Adhyaya (30/282).

Ajazuddin, Shailendra Saraf. Development of Fingerprinting Methods of Balacaturbhadrika Churna An Ayurvedic Formulation. Pharmacog Journal 2012; Volume 4, Issue 27:20 24.

Anonymous, Bhaishajya Samhita, Gujarat Rajya Bhaishajya Samiti. Ahmedabad: Published by Health Ministry, Gujarat; 1960. p. 562

Anonymous, Research Guidelines for Evaluating the Safety and Efficacy of Herbal Medicines. WHO, Regional Office, Western Pacific Region, Manila, Philippines; 1993.

Anonymous, The Ayurvedic Pharmacopoeia of India, part 2, Vol.1, 1st ed. New Delhi: Department of AYUSH, Ministry of Health and Family Welfare, Government of India; 2008. p. 43

Anonymous, The Ayurvedic Formulary of India, Part-I, Govt. India, Ministry of Health and Family Planning, Dept. of Health, India; 1998. p. 92.

Bhavamishra, Bhavaprakasha. Mishra B. editor. Varanasi: Chaukhambha Samskrta Samsthana; 1980. p. 808.

Chakradatta, Chakrapanidatta, Tripathi, J. P. editor. Varanasi: Chaukhambha Saubharati Prakashan; 1976. p. 523.

Govinda Dasa, Bhaishajya Ratnavali, Shastri A. editor. Balarogadhikara, Varanasi: Chaukhambha Samskrta Samsthana; 1983. p.747.

Jain, C. and Sharma, P. Abhinav Balatantra. Varanasi: Chaukhambha Saurbharati Prakashan; 1990. p. 142.

M V Viswanathan, P M Unnikrishnan, Katsuko Komatsu, Hirotoshi Fushimi and Purusotam Basnet. A brief introduction to Ayurvedic system of medicine and some of its problems. Indian Journal of Traditional Knowledge 2013; 2(2): 159-169

Mukeshkumar B. Nariya, Parag Parmar, Vinay J. Shukla, B. Ravishankar. Toxicological study of Balachaturbhadra churna. Journal of Ayurveda and Integrative medicine 2011; vol.2, issue 2:P.79-84.

Parag Parmar, Mukeshkumar B. Nariya, Vinay J. Shukla and B. Ravishankar. Immunomodulatory activity of Balacaturbhadrika churna-An Ayurvedic formulation. J. Med. Pharma. Sci 2011;1(2): p. 10-14. 
Raja Radhakantadeva, Shabda Kalpa Druma. Varanasi: Chaukhambha Sanskrit series; 1961, part 3. p. 451.

Sarangadharacharya, Sarangadhara Samhita, Sharma P. editor. Varanasi: Chaukhambha Amarabharti Prakashan; 1985. p. 172-175.

Shah, N. C. Bharat Bhaishajya Ratnakar, Vol. II, Unja: Motilal Banarasidas Publication; 1937. p. 131.

Shahebaz N. Ghadiyali, Nitesh Patel, Nikunj Trivedi, Hetal Desai. Development of Evaluation Parameters for Balchaturbhadra Churna \& comparision with Market Formulation, International Journal of Pharmaceutical Research \& Allied Sciences, Volume 1, issue 4 (2012), P.75-84.

Sharma P. V., Dravyaguna Vijnana. Varanasi: Chaukhambha Bharti Academy; 2001, Vol.-2. (Musta p.371; Pippali p.277; Ativisha p.356; Karkatashringi p.285).

Shastri Sadashiva, Yoga Ratnakara, Shastri B. and Shastri L. editor. Varanasi: Chaukhambha Samskrta Samsthana; 1973. p. 441.

Thomas Y.K. Chan. Aconite poisoning. Clinical Toxicology 2009; Vol. 47, No. 4: 279-285.

Vagbhata, Asthanga Hridaya, Arunadatta and Hemadri commentary, Harishastri Paradakara Vaidya editor. Varanasi: Chaukhambha Orientalia Publications; 2005, Uttara Sthana, Balamaya Pratisheda Adhyaya (2/31). p. 781.

Vridhhajeevaka, Kashyapa Samhita. Pandit Hemaraja Sharma editor. commented by Satyapala Bhishgacharya. Varanasi: Chaukhambha Sanskrit Sansthan; 2009, Khila Sthana, Bhaishjyopakramaniya Adhyaya (3/82, 83). p. 246.

Vridhhajeevaka, Kashyapa Samhita. Pandit Hemaraja Sharma editor. commented by Satyapala Bhishgacharya. Varanasi: Chaukhambha Sanskrit Sansthan; 2009, Khila Sthana, Bhaishjyopakramaniya Adhyaya (3/59). p. 245.

WHO, General guidelines for methodologies on research and evaluation of traditional medicine. World Health Organization. Geneva; 2000. 